\title{
PACIENTŲ İITRAUKIMAS KAIP INOVACIJŲ SVEIKATOS PRIEŽIŪROJE VEIKSNYS
}

\author{
Rita Vaičekauskaite் ${ }^{1}$, Gitana Skirutiené $\dot{e}^{1}$ Jonas Sąlyga ${ }^{1,2}$ \\ ${ }^{I}$ Klaipédos universitetas, ${ }^{2}$ Klaipédos jūrininku ligoniné
}

Raktažodžiai: pacientų ịsitraukimas, inovacijos, paramos grupès, sveikatos priežiūra.

\begin{abstract}
Santrauka
Šiuolaikinèje visuomenèje sveikatos priežiūra patiria didelius ir nuolatinius iššūkius. Jiems ịveikti siekiama kurti inovatyvius produktus, kurie suteiktu galimybes taikyti efektyvius gydymo būdus. Tačiau šiuolaikinė sveikatos priežiūros sistema yra labai kompleksinis reiškinys. Todèl pagrindinis iššūkis tenka sveikatos priežiūros sistemos valdymui, kuris užtikrintų šios sistemos integralumą. Šia prasme pacientų isitraukimas yra tas veiksnys, kuris turi potencialą stiprinti atskirų sveikatos priežiūros sistemos elementų darnų funkcionavimą. Tačiau pacientų įsitraukimui reikia sukurti ir palaikyti tam tikras organizacines struktūras, pavyzdžiui, savitarpio paramos grupes. Inovacijų kontekste svarbu, kad pacientų dalyvavimas būtų ne savitikslis, o kuriantis pridètinę vertę reiškinys. Todèl yra svarbi atskiru reiškinių sisteminė analizè. Straipsnyje pateikiama teorinè analizè ir empirinis tyrimas.
\end{abstract}

\section{Ivadas}

Dažniausiai nurodomos trys pagrindinès inovacijų sveikatos priežiūros sistemoje rūšys: vartotojų, technologijų, vadybos. Technologijų pažangos kontekste didelis dèmesys skiriamas produkto inovacijoms, kurios reikšmingai išplečia medicinos diagnostikos ir gydymo galimybes. Tačiau siekiant spręsti sveikatos priežiūros ekonomino efektyvumo ir socialinio tolygumo problemas, ypatingas dèmesys skiriamas vadybos inovacijoms, kurios orientuotos i skirtingų sveikatos priežiūros paslaugu ir organizacijų integralumo stiprinimą. Šiame kontekste yra svarbus klientų (pacientų) į(si)traukimas, jų sąmoningumo savo situacijos atžvilgiu stiprinimas, jų dalyvavimas sveikatos palaikymo bei stiprinimo procese. Be to, pacientų įsitraukimo stiprinimas padėtų mažinti sveikatos vartotojiškumo nuostatas ir gerintų paslaugų kokybę [1-3]. Inovacijos savo prigimtimi yra atvira ir kompleksine sistema, kurioje labai svarbi skirtingų subjektų, organizacijų komunikacija. Sveikatos priežiūroje labai stokojama komunikacijos [1]. Sistemų inovacijos yra iš daugelio elementų sudarytos naujos sistemos, kurių naujumas pasireiškia ne kaip atskirų elementų naujumas, o kaip jų pasirinkimas, naujoviškas integravimas, naujų ryšių tarp esamų sukūrimas. Sistemų inovacijos sveikatos priežiūroje siejamos su didesniu paslaugų prieinamumu ir socialinès atskirties mažinimu. Šiame kontekste dažnai siekiama optimizuoti finansines išlaidas, kurios igalintų didesnị sveikatos paslaugų prieinamumą îvairioms socialinèms grupèms. Tačiau ekonominis faktorius neturetu būti per daug sureikšminamas. Abejotina, ar gydymas taps geresnis, jei ligoninès bus pigesnès [1]. Pacientų ịsitraukimas labai svarbus, kai kalbame ne vien tik apie individą, bet apie šeimą. Vaiko negalia daro sistemini poveikị šeimai ne tik psichologiniu, bet ir socialiniu bei kultūriniu aspektais. Šeimų, auginančių vaikus su negalia, dalyvavimas savitarpio paramos grupèse stiprina sveikatos kaip socialinès patirties suvokimą, kuris igalina suvokti savo partirti kaip kultūros fenomeną, plačiaja prasme nurodanti i prasmę žmogaus gyvenime $[6,17]$. Sveikatos kultūra - tam tikroje sociokultūrinèje terpèje susiformavusios sąvokos, apibūdinančios sveikatos esmę, su sveikata susijusius dalykus [16]. Gyvenimo natūralumu ir kūrybiškumu besiremiantis negalios konceptualizavimas yra kaip atsvara mediciniškai ir psichologiškai racionaliam, tačiau per daug abstrakčiam ir kategoriškam suvokimui. Tèvų savitarpio paramos grupès yra svarbi vaiko sveikatos priežiūros sistemos dalis $[7,8]$.

Darbo tikslas: atskleisti pacientų ịsitraukimo galimybes, kurios igalintų stiprinti inovacijų sveikatos priežiūroje potencialą.

\section{Tyrimo objektas ir metodai}

Naudojant mokslinès literatūros šaltinius, atlikta konceptuali analizè. Interviu metodu apklausta 12 šeimų, auginančių vaikus su negalia. Empirinių tyrimo duome- 
nų apdorojimui naudota turinio (angl. content) analizè.

Pacientų ịsitraukimo prielaidos sveikatos priežiūros sistemos aspektu. Pacientų įsitraukimas yra skètinè sąvoka ir kompleksinis reiškinys. Kad įsitraukimas būtų efektyvus, jis turetų vykti kaip nuolatinis, o ne vienkartinis įvykis, kuris stiprina grị̌žtamaji ryši sveikatos priežiūros sistemoje [12].

Pacientu įsitraukimo prielaidas sudaro sveikatos priežiūros sistemos tapsmas naujos kokybės kompleksiniu reiškiniu. Šiandienineje visuomenejje niekas neabejoja, kad sveikatos priežiūros sistemos efektyvumui yra svarbus pacientų dalyvavimas ir ịsitraukimas. Tačiau vyksta nuolatinè paieška būdų, koks turètų būti sveikatos priežiūros valdymas, kad pacientų ịsitraukimas būtų ne savitikslis veiksmas, o kurtų pridètinę vertę. Šia prasme sveikatos priežiūros integralumas išlieka iššūkiu. Sąlygiškai galima išskirti tris sveikatos priežiūros integralumo lygmenis, kurie sąveikauja su kompleksiškumo poreikiu (1 pav.) [15].

Inovacijos savo esme yra reiškinys, kuriam svarbus yra (eko)sistematiškumas. Moksliniai tyrimai rodo, kad inovacijos sẻkmingai kuriamos ne monopolinèje ar izoliuotoje terpejje, o sąveikaujant daugeliui veikèjų: mokslininkams, vadybininkams, inovatyvioms įmonems, kompetentingiems žmonèms, informacinèms infrastruktūroms [9]. Todèl yra konceptualios prielaidos manyti, kuo labiau kompleksiška yra sveikatos priežiūra, tuo aukštenis inovacijų potencialas, kurị sudaro atskirų segmentų kokybiškai nauja tarpusavio sąveika (1 pav.).

Kalbant apie sveikatos priežiūros integralumą, svarbu ne tik atskirų jos struktūrinių dalių ar funkcijų tarpusavio instrumentinis suderinamumas, bet ir skirtingų požiūrių, skirtingų medicinos sistemų dermè mikro- ir makro- lygmenyse $[13,18]$. Dirbti su pacientų įsitraukimu, reiškia dirbti ne tiek su žinių, kiek su požiūrio sistemomis, kurių

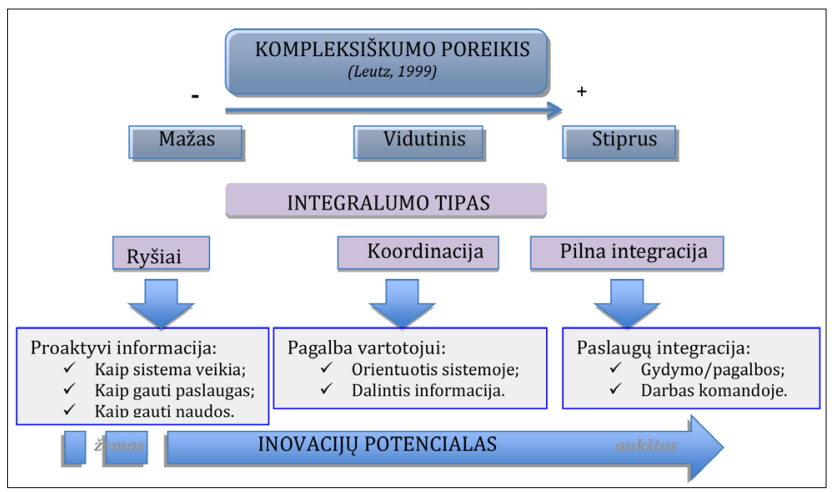

1 pav. Sveikatos priežiūros integralumo ir inovatyvumo konceptualūs ryšiai

(shemos šaltinis 13; modifikuota straipsnio autoriu) valdymui reikia specifinių kompetencijų. Panašių požiūrių pagrindu žmonès organiškai jungiasi i grupes, kurios igalina savitarpio socialinei psichologinei paramai. Tačiau šių grupių efektyviam valdymui kaip integraliam sveikatos priežiūros reiškiniui reikia ir kompetencijų, ir atitinkamos struktūros. Kai kuriose šalyse prielaidos paramos grupių integralumui sveikatos priežiūroje yra labai aukštos, pavyzdžiui, keturi iš dešimties amerikiečiu priklauso kokiai nors savitarpio paramos grupei [10]. Tačiau net ir esant minètoms prielaidoms, pacientų savitarpio paramos grupés stokoja institucionalizuoto integralumo sveikatos priežiūros sistemoje.

Tẻvų savitarpio paramos fenomenas ir jo kompleksiškumas. Tèvų savitarpio paramos grupès nèra naujas reiškinys, tačiau jis įgauna naują prasmingumą, kai kalbame apie ji inovacijų kontekste. Šio reiškinio fenomenalumu ir nauda klientams niekas neabejoja, be to, yra daug mokslinių tyrimų duomenų apie tai $[5,10]$. Tačiau ligšioliniuose tyrimuose didesnis demesys buvo skiriamas, kokią naudą tẻvų savitarpio paramos grupès neša klientui kaip individui ar grupei (t. y. šeimai), o ne sveikatos sistemai.

Savitarpio paramos grupè (angl. support group) neturètų būti sutapatinama su savipagalbos grupe (angl. self-help group). Skiriasi minètu grupių pirminiai tikslai. Savipagalbos grupè yra orientuota ị asmens pokyčius. Šios grupès sudaromos iš asmenų, kuriuos jungia bendra gyvenimo problema. Savitarpio paramos grupe pirmiausia orientuota $i$ emocinès paramos ir informacijos suteikimą. Bet tai nereiškia, kad savitarpio paramos grupėse negali ịvykti asmenybės pokyčiai. Dažnai ir savitarpio paramos grupèse vyksta paminèti asmenybès pokyčiai, tačiau jie nèra pagrindinis šių grupių darbo tikslas. Analogiškai galima pasakyti apie savipagalbos grupes. Dažnai jos taip pat suteikia asmeniui emocinę ir informacinę paramą, bet tai nèra pagrindinis šių grupių veiklos tikslas.

Abiem grupèms bendra tai, kad jos suteikia pagalbą panašiais aspektais [5]:

- Išplečia asmens socialinį tinklą. Žmogus gali jaustis nebe vienišas su savo problema ar būkle. Kai žmonès jaučiasi priklausą bendruomenei, jiems lengviau kovoti su neigiamomis visuomenès nuostatomis jų atžvilgiu. Afiliacija su panašaus likimo žmonėmis sustiprina asmens viltí, pasitikèjimą, palengvina gèdos jausmą.

- Lavina, suteikia informaciją, organizuodamos paskaitas, seminarus. Žmonès, kurie dalyvauja savipagalbos arba savitarpio paramos grupėse, daugiau naudojasi ir specialistų pagalba. Manoma, kad taip yra dèl to, kad šiose grupèse jie gauna informacijos apie galimus pagalbos šaltinius.

- Sustiprina priklausymo grupei ar bendruomenei jausmą, kuris reikšmingas identitetui. 
- Moko susidorojimo su problemomis ịgūdžių. Dažnai tai nèra specialus mokymas kaip terapinèse grupèse. Igūdžiai susiformuoja per bendravimą, pavyzdžiui, išmokstama savistabos, todèl mažiau konfliktuojama.

Savitarpio paramos grupès užtikrina paramą, mažina stresą, skatina siekti pasikeitimų gyvenime. Tẻvams sudaroma saugi erdvè dalintis savo išgyvenimais, plèsti socialinius ryšius, vystyti iniciatyvas. Jie aptarinejja rūpimas problemas, dalinasi patirtimi, ieško savo problemų sprendimo būdų. Grupè gali parodyti, kad asmuo nèra vienas su savo problema. Labiausiai žmones ị grupes traukia galimybès palaikyti bendravimo santykius. Nepaisant to, kad žmogui akivaizdi dalyvavimo grupèje nauda, aktualiausia problema išlieka, kaip pritraukti žmones dalyvauti savitarpio paramos grupèse $[5,10]$.

Kaip rodo užsienio šalių patirtis, dauguma tų, kurie pradeda lankyti savitarpio paramos grupes, greitai savo dalyvavimą nutraukia. Manoma, kad žmonès nenoriai lanko grupes dèl to, kad jie yra pažeisti streso. Žmonių motyvaciją lankyti grupes sustiprina tai, kad jie geriau pasijunta sutikę panašius ị save žmones, ir tai, kad grupe atliepia asmens poreikius. Labai svarbu, kad žmonės kuo ilgiau lankytų savitarpio paramos grupes, nes naudą gauna tik tada, kai pakankamai ilgai joje dalyvauja. Svarbus veiksnys, motyvuojantis dalyvauti grupès veikloje, yra asmeninè filosofija arba požiūris į gyvenimą. Pavyzdžiui, jei žmogus yra tikintis Dievą ir grupejje sutinka tokių pat žmonių, jo motyvacija likti grupejje labai sustiprèja. Dalyvavimo grupejje motyvacijai reikšmès turi ir asmenybès savybès. Jeigu asmuo yra ekstravertas, linkęs bendrauti, dalintis savo patirtimi ir išgyvenimais, jis labiau negu kiti yra linkęs dalyvauti grupejje. Akivaizdu, kad priklausymo grupei nauda socialinès pagalbos prasme yra akivaizdi, tačiau poreikis priklausyti grupei-afiliacija- daugeliu atvejų atsiranda ne iš karto, o praeinant tam tikrus etapus $[7,8,10]$.

Tẻvų, auginančių vaikus su negalia, požiūris ị savitarpio paramos galimybes. Vienas labiausiai žmones lankyti savitarpio paramos motyvuojančių veiksnių yra siekimas surasti panašius i save:

Kai sutinki panašų, visada geriau jautiesi [1]. Tikrai jaučiuosi geriau, kai pabendrauju su panašią patirtị turinčiais tèvais [2]. Manau, kad panašiu problemų turintys tèvai jaučiasi panašiai ir išgyvena panašius jausmus - susitaikymą su tuo išgyvenimu, savęs kaltinimą, kitų kaltinimą [4]. Tiesiog tie žmonès patys linkę labiau klausytis apie mūsų situaciją, nes jiems tai yra aktualu, o žmonès, kas nèra susidūrę su tokia situacija, jie nelabai ir nori $i$ ją gilintis [5]. Tačiau, žinoma, kiekvienas, o ypač mes, norime būti išklausyti, o kas tave geriau supras, ne apsimes, jei ne panašią patirtị turintys žmonès [7]. Kuo panašesnè negalè, tuo greičiau galima pajusti, jog panašiai vertiname situaciją, turime nuomonę tais pačiais klausimais [8]. Geriau jaučiuosi, kai sutinku žmonių, kurie labai panašiai jaučiasi ir mąsto kaip aš [10]. Tẻvai, su kuriais aš draugauju, labai palaiko mane ir vienas kitą, tai labai svarbu [11]. Žinoma, kad šeimos, turinčios panašią patirti, lengviau vieni kitus supranta, o moralinis palaikymas suteikia daugiau pasitikèjimo [12].

Bendravimas su panašios patirties turinčiais žmonėmis padeda:

- Sumažinti įtampą.

Išsikalbejjus jautiesi geriau, atslūgsta ịtampa, kuri yra gan dažnas svečias [10].

- Sustiprinti viltį ir optimizmą.

Vien buvimas šalia, galimybè bendrauti, matyti likimo brolius ir seses, suteikia stiprybès ir vilties [7].

Panašios patirties tèvai padrąsina ir suteikia optimistiškų minčių [6].

- Formuoja gebèjimus ir ịgūdžius vaiko priežiūros klausimais.

Gauti informaciją iš tokių pat tèvų labai aktualu, nes ši informacija suteikia galimybę padèti sergančiam vaikui [3].

- Skatina tèvų aktyvumą, kūrybiškumą.

Kartais klausydama svetimų pasakojimų, matai savaji gyvenimą, savas situacijas [3]. Bendraujant su panašios patirties tèvais kelias ị savarankiškumą, išradingumą ir aktyvumą praplatėja, o ne susiaureja [10]. Bendravimas ịpareigoja būti aktyviems, padèti sau ir kitiems, būti išradingiems [12].

- Padeda gauti reikalingos informacijos ịvairiais klausimais.

Informacijos, kaip minejau, labai labai trūksta, pavyzdžiui, dèl masažų, mankšteliụ, kur kreiptis dèl baseinų, kur geriau, kur priežiūra geresnė [4]. Informacijos reikia ir norisi visokios sprendžiant auklèjimo, priežiūros, socialinių reikalų bei kitokius klausimus, pagaliau kartais net teisinius klausimus [7]. Noréčiau išmokti planuoti ateiti, kuri būtu priderinta prie mano ir mano vaiko galimybės [8]. Visokios informacijos dar trūksta - kaip integruotis ị visuomenę, kaip elgtis, kad būtum priimtas, kaip pilnateisis visuomenès narys [9]. Noréčiau gauti man ir mano vaikui naudingos informacijos [10].

- Padeda įgyti žinių, paremtų konkrečiomis patirtimis (angl. experiental knowledge).

Man aktualu gauti informacijos, kuri yra sukaupta kitų tèvų, auginančių raidos problemų turintị vaiką, nes padeda išspręsti problemas, kurios, neturint informacijos, atrodo neišsprendžiamos [8]. Bendraujant su panašios patirties tèvais kelias ị savarankiškumą, išradingumą ir aktyvumą praplateja, o ne susiaurejja [10].

Savitarpio paramos refleksijos rodo, kad svarbu skatinti ir palaikyti socialinius reiškinius, kurie būtų orientuoti ì neiggaliujų mikrokultūros palaikymą, o ne tik projektus, kuriais neigalieji siekia priartèti prie sveikuju visuomenès raiškos normų ir standartų [14]. Kai kurių tyrinètojų požiūriu, žmonès, turintys tam tikros rūšies ypatingumus, gali sukurti savo mikrokultūras [4]. Taigi savitarpio paramos grupès gali būti vertinamos kaip tam tikras sociokultūrinis reiškinys. Kultūros aspektas yra toks svarbus, kad darbo su 
savitarpio paramos grupėmis sẻkmè didele dalimi priklauso nuo gebejjimo šias grupes vystyti kaip kultūros reiškinį, kuris turi savo simboliką ir naratyvą [10].

\section{Išvados}

Pagrindinis iššūkis, kurị patiria šiuolaikinè sveikatos priežiūra, yra jos atskirų dalių tarpusavio integralumas. Dažnai kalbant apie sistemos integralumą apsiribojama jos atskiru dalių suderinimo instrumentinėmis priemonėmis. Tačiau per mažai skiriama dèmesio komunikacijai. Dirbti su pacientų įsitraukimu, reiškia dirbti ne tiek su žinių, kiek su požiūrio sistemomis, kurių valdymui reikia specifinių kompetencijų.

Sveikatos priežiūros sistemos kompleksiškumas yra pozityvus reiškinys, nes jis sudaro aukštą inovacijų potencialą. Tačiau kompleksinès sistemos ir ị inovacijas orientuotam valdymui yra labai svarbus paciento įsitraukimas.

Savitarpio paramos grupès yra kompleksinis reiškinys, kuris turi potencialą ịvairiais aspektais stiprinti pacientų issitraukimą.

\section{Literatūra}

1. Chin WW. et al. 5 Imperatives addressing healthcare's innovation challenge. Prieiga per internetą: http://www.hbs.edu/ healthcare/Documents/Forum-on-Healthcare-Innovation-5-Imperatives.pdf

2. Foot C. et al. People in control of their own health and care. The state of involvement. 2014.

3. Herzlinger RE. Why innovation in health care is so hard 2006. Prieiga per internetą: https://hbr.org/2006/05/why-innovationin-health-care-is-so-hard

4. Hallahan D.P., Kauffman J.M. Ypatingieji mokiniai. Specialiojo ugdymo įvadas. Vilnius, 2003.

5. Kurtz LF. Self-Help and support groups. Sage publications 1997.

6. Levesque A, Zi HL. The relationship between culture, health conceptions, and health practices: a qualitative-quantitative approach. Journal of cross-cultural psychology 2014; 45(4):628-645.

http://dx.doi.org/10.1177/0022022113519855

7. Lefevre A. et al. Managing parental groups during early childhood: New challenges faced by Swedish child health-care nurses. Journal of Child Health Care 2015; 19(3) 381-391.

8. Mandell DS. Salzer MS. Who joins support groups among parents of children with autism? Autism 2007; 11(2) 111-122.

9. Melnikas B. et al. Žinių ekonomikos kūrimas: inovacijų paramos sistema. Vilnius, 2011.
10. Mohr WK. The substance of a support group. Western journal of nursing research 2003; 25(6): 676-692. http://dx.doi.org/10.1177/0193945903253982

11. Omachonu VK, Einspruch NG. Innovation in healthcare delivery systems: a conceptual framework. The innovation journal: the Public Sector Innovation Journal 2010; 15(1).

12. Ridley J, Jones L. User and public involvement in health services: a Literature Review 2000.

13. Robinson A. et al. Beyond a Generic complementary and alternative medicine: The Holistic Health Care - Conventional Medicine Continuum. Complementary Health Practice Review 2009; 14(3) 153-163.

14. Ruškus J., Mažeikis G. Neịgalumas ir socialinis dalyvavimas. Šiauliai. ŠU leidykla, 2007.

15. Stanislao FD. et al. Integrated systems and continuity in health care: a navigation through the concepts and models. International Journal of Care Pathways 2011; 15: 82-89. http://dx.doi.org/10.1258/jicp.2011.011008

16. Šveikauskakas V. Sveikatos edukologija. Kaunas. LSMU, 2008.

17. Tomlinson J. Globalizacija ir kultūra. Vilnius, Mintis, 2002.

18. Vliet M. et al. Attitudes, beliefs, and practices of integrative medicine among nurses in the Netherlands. Journal of Holistic Nursing American Holistic Nurses Association June 2015; 33(2):110-121.

http://dx.doi.org/10.1177/0898010114555339

\section{PATIENTS' INVOLVEMENT AS FACTOR FOR INNOVATIONS IN HEALTH CARE}

R. Vaičekauskaitė, G. Skirutienė, J. Sąlyga

Key words: patients' involvement, innovations, support groups, health care.

Summary

Health care faces great and constant challenges in contemporary society. On the one hand, there is a policy to encourage creation of new products, which enable for effective treatment. On the other hand, the main challenge is related with effective management of huge complexity in health care system. Patients' involvement has a great potential for integration in health care. However, it is important to create organizational structures (i.e. support groups). Furthermore, it is important to ensure that patients' involvement generate added value. Article presents theoretical analysis and empirical results.

Correspondence to: sekretore@jurlig.lt

Gauta 2015-11-29 